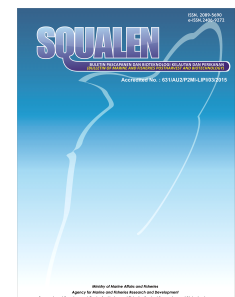

\title{
BACTERIAL DIVERSITY OF A MICROBIAL MAT FROM HOT SPRING AT WARTAWAN BEACH, LAMPUNG AND ITS POTENTIAL AS A SOURCE OF HYDROGENASES
}

\author{
Gintung Patantis ${ }^{1 *}$, Ekowati Chasanah"), Yusro Nuri Fawzya'), He Pei Qing ${ }^{2)}$, and Zhang Xue Lei ${ }^{2)}$ \\ 1) Research and Development Center for Marine and Fisheries Product Processing and Biotechnology, \\ JI. KS Tubun Petamburan VI, Jakarta 10260, Indonesia \\ 2) The Key Laboratory of Marine Bioactive Substances, The First Institute of Oceanography, State Oceanic Administration, \\ 6 Xianxialing Road, Hightech Park, Qingdao 266061, Shandong, People's Republic of China \\ Article history: \\ Received: 13 March 2018; Revised: 15 April 2018; Accepted: 17 May 2018
}

\begin{abstract}
Biohydrogen produced from thermophilic hydrogenases is an ideal and clean energy sources. As the biggest tectonic area in the world, Indonesia is potential for thermophile isolation. The aims of this study were to analyze the bacterial diversity of a microbial mat from hot spring at Wartawan beach, Lampung and to analyze the potency of microbial mat for hydrogenases, using clone library method. The diversity of $16 \mathrm{~S}$ rRNA showed that the microbial mat sample contained 9 phyla of bacteria, and dominated by Cyanobacteria and Proteobacteria. These phyla indicate that the bacterial community of the microbial mat consisted of phototrophic and heterotrophic groups. In addition, a microbial mat of Wartawan beach environment might be influenced by marine environment and hydrothermal vent which was indicated by detection of both associated bacteria. The diversity of hydrogenase genes using $\mathrm{NiFe}$ hydrogenase (NiFe) and FeFe hydrogenase (FeFe) genes showed that Cyanobacteria was specifically related to NiFe, while Firmicutes was associated with FeFe. Proteobacteria and Bacteroidetes, however, were detected for both genes. The detected hydrogenase genes indicate that the microbial mat from hot spring at Wartawan beach is a promising source for hydrogenases isolation and further applications for biohydrogen production as a renewable energy.
\end{abstract}

Keyword: diversity, bacteria, hydrogenases, microbial mat, hot spring Wartawan beach

\section{Introduction}

The hyper-consumption of fossil fuel and global warming have led to the global effort of replacing fossil energy with renewable sources. As an ideal and clean energy carrier, hydrogen $\left(\mathrm{H}_{2}\right)$ is one of the future energy resource due to high conversion, recyclable and nonpolluting (Karadag, Mäkinen, Efimova, \& Puhakka, 2009). Recently, hydrogen is commercially produced from water or hydrocarbon using high energy and unsustainable processes (Das \& Veziroglu, 2008). Biohydrogen, however, has attracted many research interests because of low cost and inexhaustible (Show, Lee, Tay, Lin, \& Chang, 2012). In addition, the biological process of hydrogen production could use carbon and energy sources from organic pollutants (Li \& Fang, 2007). This process is catalyzed by special group of enzymes called hydrogenases which catalyze the reversible oxidation of molecular hydrogen following the reaction of $\mathrm{H}_{2} \Leftrightarrow 2 \mathrm{H}^{+}+2 \mathrm{e}^{-}(\mathrm{Kim} \& \mathrm{Kim}, 2011)$.

Hydrogenases are divided into three major classes based on the metal cofactors at the active sites, namely Fe-hydrogenase (FeFe), NiFe hydrogenase $(\mathrm{NiFe})$ and the metal free hydrogenase $(\mathrm{Fe})$ (Vignais, Billoud, \& Meyer, 2001). The FeFe is known produced by anaerobic bacteria and a few of green algae (Boyd, Spear, \& Peters, 2009), while NiFe is found in hyperthermophilic archaea and microorganisms that use hydrogen (Eberly \& Ely, 2008). Hydrogenases can be produced by both mesophiles and thermophiles, however thermophilic hydrogenases are more promising sources. Thermophilic bacteria produced more $\mathrm{H}_{2}$, utilized variety organic waste and produce fewer fermentations by products compared to mesophiles (Karadag et al., 2009).

\footnotetext{
*Corresponding author.

E-mail: gintungpatantis@gmail.com
} 
The isolation and studies of microbial hydrogenases diversity have been well studied from several environments, including from saline mat (Boyd et al., 2009), hot spring (Karadag et al., 2009; Minnan et al., 2005), marine and fresh waters (Barz et al., 2010; Kothari, Potrafka, \& Garcia-Pichel, 2012), anaerobically-digested sludge (Quéméneur et al., 2011), acidophilic sludge (Fang, Zhang, \& Li, 2006), acidophilic ethanol-H2-coproducing system (Xing, Ren, \& Rittmann, 2008). Those microorganisms include anaerobes (Clostridia, Methylotrophs, methanogenic bacteria, Rumen bacteria, archaea), facultative anaerobes (Escherichia and Enterobacter), aerobes (Alcaligenes and Bacillus), photosynthetic bacteria, and Cyanobacteria (Nandi \& Sengupta, 1998). Study on the hydrogenase diversity in Indonesian environment, however is still limited. A study on FeFe hydrogenase was reported from seaweed associated with hot springs of Kalianda, Lampung (Xu et al., 2013).

As the biggest tectonic area in the world, Indonesia has various areas with elevated temperature, which are the source of thermophiles. The hot environments are spread in many locations, not only in the land but also coastal environments including deep sea area. Some of these areas are located at Tambrana, Central Sulawesi (Zilda, Kusumarini, \& Chasanah, 2008), Poso, Central Sulawesi (Zilda, Patantis, \& Chasanah, 2009), Padang Cermin and Kalianda, Lampung and Banyu Wedang, Bali (Zilda et al., 2012). These hot environments are characterized by a mat layer, made up from microbial mat communities. The microbial mat are formed of cohesive microbial accumulations in the sediment or water surface (Guerrero, Piqueras, \& Berlanga, 2002) and dominated by bacteria and archaea (Schieber et al., 2007). Research on the microbial mat have attracted attention since it is potential as thermophilic sources and has good

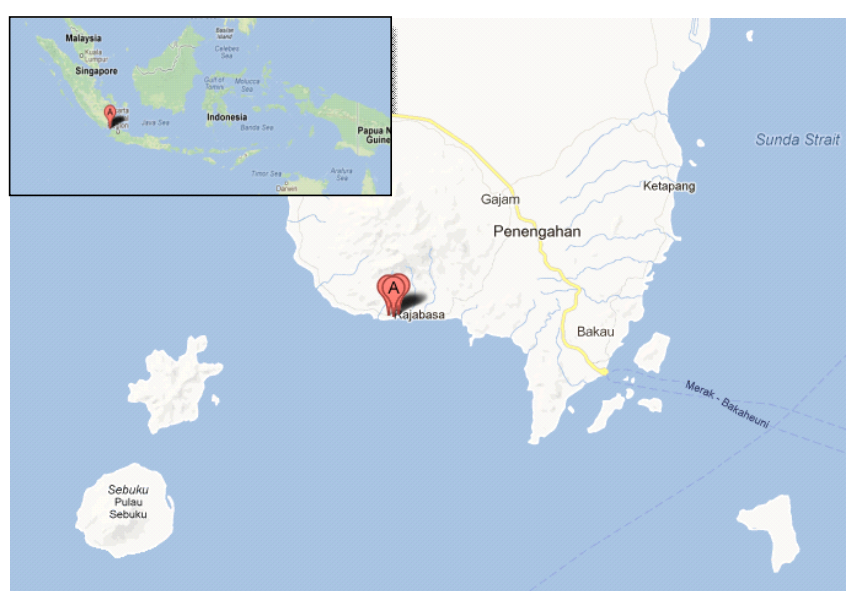

(a) biotechnological prospects (Ward, Ferris, Nold, \& Bateson, 1998). Therefore, the aims of this study were to analyze the bacterial diversity of a microbial mat from hot spring at Wartawan beach, Lampung using clone library technique and the potency of the microbial mat as hydrogenases source by detecting the hydrogenase genes.

\section{Material and Methods}

\subsection{Sample Collection}

A solid microbial mat sample was collected from Wartawan beach hot spring, Lampung, Sumatera, Indonesia (5.83'63" S, 105.62'89" E) in July 2011 (Figure 1). The microbial mat was collected, put in the sterile bottle and transported at room temperature before stored at $-20^{\circ} \mathrm{C}$. The environmental conditions were recorded, including temperature, salinity, and $\mathrm{pH}$.

\subsection{Genomic DNA Extraction and Genes Amplification}

Genomic DNA extraction was conducted using Fast DNA Spin Kit for Soil (MP Bio, USA) according to the manufacturer's instruction. Universal primer was used for amplification of 16S rRNA gene, forward: 52 AGAGTTTGATCMTGGCTCAG32 and reverse primer 52 AAGGAGGTGATCCANCCRCA3 (Xu et al., 2013) and FeFe (FeFe-272F: 5-GCHGA YMTBACHAT WATGGARGA-3 and FeFe-427R: 5-GCNGCYT CCATDACDCCDCCNGT-3), NiFe (HoxH-f GTATYTGY GGYATTTGTCCTGT and HoxH-r GGCATTTG TCCTRCTGYATGTGT) for hydrogenase genes (Barz et al., 2010; Schmidt, Drake, \& Horn, 2010).

The PCR mixture $(50 \mu \mathrm{L})$ was composed of 0.40 $\mu \mathrm{L}$ primer, $25 \mu \mathrm{L}$ of Taq polymerase Mix (Tiangen Ltd.,

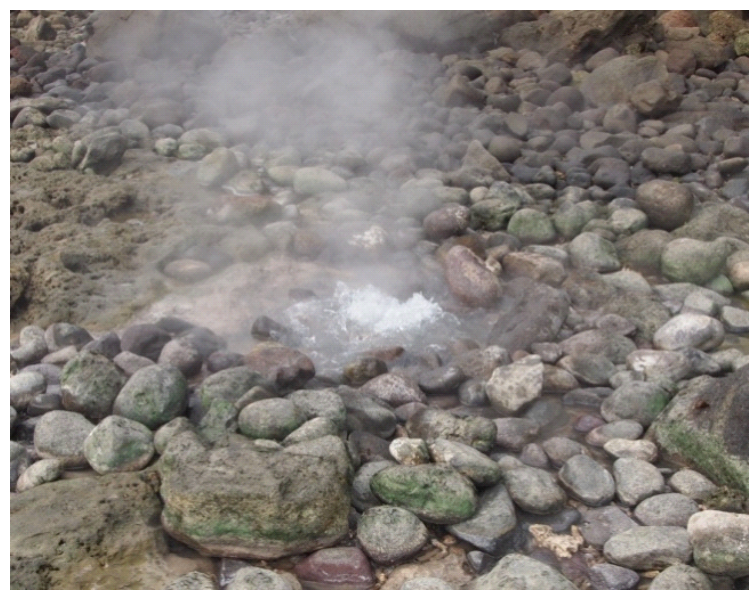

(b)

Figure 1. Location of sample collection (http://maps.google.co.id) (a) and hot spring at Wartawan beach (b) 
China), and $2 \mu \mathrm{L}$ of template genomic DNA. The PCR reaction for $16 \mathrm{~S}$ rRNA consisted of initial denaturation at $95^{\circ} \mathrm{C}$ for 5 minutes and 30 cycles of denaturation at $95^{\circ} \mathrm{C}$ for 1 minute, annealing at $55^{\circ} \mathrm{C}$ for 0.5 minute, elongation at $72^{\circ} \mathrm{C}$ for 1.5 minutes and final elongation at $72^{\circ} \mathrm{C}$ for 10 minutes. While for hydrogenase, the PCR reactions consisted of initial denaturation at $95^{\circ} \mathrm{C}$ for 5 minutes and 40 cycles of denaturation at $95{ }^{\circ} \mathrm{C}$ for 0.5 minutes, annealing at $50{ }^{\circ} \mathrm{C}$ for 0.5 minutes, elongation at $72{ }^{\circ} \mathrm{C}$ for 1.5 minutes and final elongation was at $72^{\circ} \mathrm{C}$ for 10 minutes.

\subsection{Clone Library Construction}

PCR products of $16 \mathrm{~S}$ rRNA and hydrogeanse genes were purified using a Nucleo Spin Extract II kit (Tiangen Ltd., China) and ligated into P easy-T1 cloning kit (Trans Gene Biotech, China). The ligated vectors then were transformed into Escherichia coli DH5a cells competent. The positive clones were analyzed using primers M13F (50 - GTAAAACGACGGCCAGT-30) and M13R (50-CAGGAAACAGCTATGAC-30) and sequenced at Jin Sirui, China.

\subsection{The $\alpha$ Diversity Analysis}

The similarity of each clone sequence of 16S rRNA (800 bp fragment) was analyzed using the CodonCode Aligner software (CodonCode Corporation, Massachusetts, USA) (Xu et al., 2013). The similarity of sequences above $95 \%$ were determined as one phenotype (OTU). While for hydrogenase gene (FeFe and $\mathrm{NiFe}$ ) the sequences were firstly translated into amino acid with DNASTAR Megalign software (DNASTAR Inc., Madison, USA) (Xu et al., 2013) before analyzing through CodonCode Aligner with parameter similarity of $99 \%$. The $\alpha$ diversity parameters including equitability $(\mathrm{J})$, simpson (1-D) and Shanon $(\mathrm{H})$ were calculated using Past Statistical Software v3.08 (Hammer et al., 2001). The coverage (C) was determined according to Good (1953) with equation C $=(1-$ (number of OTUs/ total clones $) \times 100 \%$.

\subsection{Phylogenetic Analysis}

The 16S rRNA sequences with similarity of $95 \%$ were determined to the same phylotype and translated to the bacteria species using the Basic Local Alignment Search Tool (BLAST) in GenBank. While, the amino acid hydrogenase gene sequences with 99\% similarity were identified using Protein BLAST. Phylogenetic trees of 16S rRNA and hydrogenases were constructed using the Molecular Evolutionary Genetics Analysis package (MEGA version 7.0) (Kumar, Stecher, \& Tamura, 2016) using Test Maximum Parsimony tree method. Bootstraps of
1,000 were performed to assign the confidence levels to the nodes of the trees.

\section{Results and Discussion}

\subsection{The Environmental Conditions of Sampling Location}

The environmental conditions measurement on temperature, $\mathrm{pH}$ and salinity of hot spring at Wartawan beach were $98^{\circ} \mathrm{C}, 4$ and $5 \%$ respectively. Lampung is known as hot spring spots, for instane, in Kalianda, Padang Cermin (Zilda et al., 2012) and Wartawan beach. The presence of hot springs is mainly associated with volcano activity in the area (Kruse, 1999). In the case of Lampung region, these hot springs might be related to the presence of the active volcano Anak Krakatau in Lampung erupted in 1888. Compared to other hot springs (Table 1), the temperature and salinity of hot spring at Wartawan beach were similar with Padang Cermin, while the $\mathrm{pH}$ was similar to Tambrana hot spring. The similarity and difference between environment characteristics of these hot spring might be related with their location and water influenced. The hot spring observed in the study is located in the Wartawan beach and influenced by tidal process, while the hot spring at Padang Cermin and Tambrana are not affected by tidal. In addition, as stated by Kurse, the characteristics of hot spring were influenced by rock permeability, composition, structure and the availability of surface water and materials (Kruse, 1999). Further, the environment factors (temperature, $\mathrm{pH}$, hydrogen, oxygen and geological) determine the diversity communities of microorganisms (Chen et al., 2017; Lau, Aitchison, \& Pointing, 2009) and their potential application (Karadag et al., 2009).

\subsection{The $\alpha$ diversity of Bacteria and Hydrogenase Genes}

Assessment on the diversity of bacteria in a microbial mat of hot spring at Wartwan beach was conducted by analyzing the $16 \mathrm{~S}$ rRNA gene. Whereas the potency of hydrogenase producers was determined by detecting the FeFe and NiFe hydrogenase genes. A total of 118, 49 and 48 clones were analyzed for Bacteria (16S rRNA) and FeFe and NiFe genes respectively. Using Codon Code Aligner software, the number of OTUs were 53 for $16 \mathrm{~S}$ rRNA, 19 for FeFe and 9 for NiFe (Table 2). The coverage of genes diversity was from 55.08 to $81 \%$. The coverage illustrates the level of sample adequacy in the analysis. The coverage between 51 to $80 \%$ would be representative to indicate the diversity of microbes in the communities (Lemos, Fulthorpe, Triplett, \& 
Table 1. The environmental conditions of hot spring at Wartawan beach, Lampung and other locations

\begin{tabular}{lcccl}
\hline \multicolumn{1}{c}{ Locations } & Temperature $\left({ }^{\circ} \mathbf{C}\right)$ & pH & Salinity (\%) & \multicolumn{1}{c}{ References } \\
\hline Wartawan beach, Lampung & 98 & 4 & 5 & This study \\
Padang Cermin, Lampung & 97 & 6.9 & $4-5$ & Zilda et al. (2012) \\
Kalianda, Lampung & $58.5-68.5$ & $6.0-6.5$ & 4 & Xu et al. (2013) \\
Banyu Wedang, Bali & 44.8 & 8.1 & 4 & Zilda et al. (2012) \\
Tambrana, Central Sulawesi & 50 & 4.9 & 20 & Zilda et al. (2008) \\
\hline
\end{tabular}

Table 2. The $\alpha$ diversity of $16 \mathrm{~S}$ rRNA and hydrogenase genes from a microbial mat of hot spring at Wartawan beach, Lampung

\begin{tabular}{lcccccc}
\hline Gene & $\begin{array}{c}\text { Number of } \\
\text { clones }\end{array}$ & OTUs & Coverage (\%) & J & 1-D & H' \\
\hline 16S rRNA & 118 & 53 & 55.08 & 0.85 & 0.94 & 3.38 \\
FeFe & 49 & 19 & 61.22 & 0.78 & 0.81 & 2.29 \\
NiFe & 48 & 9 & 81.25 & 0.68 & 0.67 & 1.48 \\
\hline
\end{tabular}

Roesch, 2011). However, the diversity obtained in this study could be increased by increasing the number of the clones being analyzed. There are some issues that should be considered when analyzing the diversity from clone library, such as PCR primer selection, screening process, OTUs determining (Lau et al., 2009). The equitability $(\mathrm{J})$ and Simpson's indices (1D) of the $16 \mathrm{~S}$ rRNA and FeFe showed that the species were equally distributed in the communities, whereas in the NiFe had a domination in one or a few species. A low number of equitability and Simpson's indicated that the population was dominated by one or a few individuals (Morris et al., 2014). Both $16 \mathrm{~S}$ and FeFe genes had a higher diversity index which was showed by high number of Shanon's (3.38 and 2.29 respectively).

\subsection{Bacterial and Hydrogenase Genes Compositions}

Bacteria structure of the microbial mat from hot Spring at Wartawan beach, Lampung was comprised of 9 phyla, including Acidobacteria, Bacteroidetes, Cyanobacteria, Candidate divisions, DeinococcusThermus, Firmicutes, Planctomycetes, Proteobacteria and others that not classified yet into phyla (Figure 2). These phyla indicated that the bacterial community of microbial mat consist of phototrophic and heterotrophic groups. In addition, Cyanobacteria was the most abundant group with more than $40 \%$ followed by Proteobacteria (16\%). Cyanobacteria and Proteobacteria in many mat microbial community types were considered as major components (Guerrero et al., 2002; Lau et al., 2009; Moyer, Dobbs, \& Karl, 1995; Preisner, Fichot, \& Norman, 2016). The presence of Cyanobacteria as a phototrophic plays role for primary producers to support the mat communities (Lau et al., 2009). Cyanobacteria use water as an electron donor in the oxygenic photosynthesis. Therefore, they could be found in almost any environment types from terrestrial, fresh to salt water and extreme conditions (Tamagnini et al., 2007). While Proteobacteria especially lithotrophic group is known as iron oxidizers microbial which support energy to other trophic levels (Fullerton, Hager, McAllister, \& Moyer, 2017) as they reduce high concentrations of metals that available in the hydrothermal vent system (Hager, Fullerton, Butterfield, \& Moyer, 2017). Chloroflexi and Thermotogae phyla are also known inhabited in mat environments (Amin et al., 2017), however in this study these phyla were not detected. In addition to the method used, the differences may be because of different physical and chemical conditions, as temperature, $\mathrm{pH}$ and physio-chemical parameters influence the structure of microbial in the thermal spring (Amin et al., 2017; Chen et al., 2017).

Compared to the bacteria structure, the hydrogenase genes were less diverse, recorded only 6 and 4 phyla for FeFe hydrogenase and NiFe 


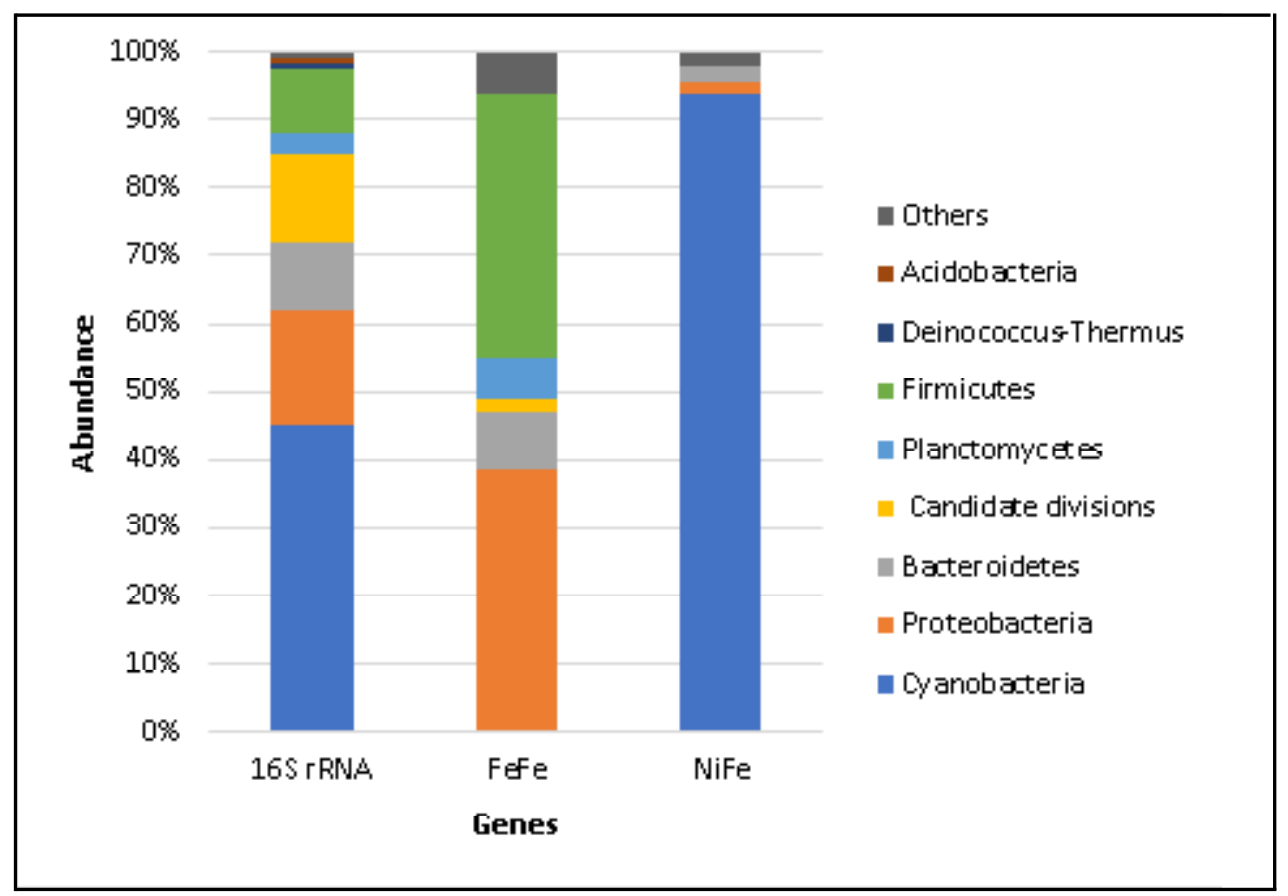

Figure 2. Bacterial and hydrogenase genes compositions of a microbial mat from hot spring at Wartawan beach, Lampung at the phylum level. A total of 118,49 and 48 clones were analyzed for 16 S rRNA and FeFe and NiFe genes respectively. The number of OTUs were 53 for $16 \mathrm{~S}$ rRNA and 19 for FeFe and 9 for NiFe.

respectively (Figure 2). Proteobacteria and Firmicutes were shared the biggest phyla in FeFe, followed by Bacteroidetes, Planctomycetes and Candidate Division. Similarly, the diversity of FeFe hydrogenase bacteria community in paddy field soil was dominated by Proteobacteria and Firmicutes (Baba, Asakawa, \& Watanabe, 2016). In addition, FeFe hydrogenase from saline microbial mat ecosystem in Mexico showed that Firmicutes was the most abundant group (Boyd et al., 2009). On the other hand, hydrogenase gene related to Cyanobacteria dominated in $\mathrm{NiFe}$ hydrogenase followed by $\mathrm{NiFe}$ genes related to Bacteroidetes and Proteobacteria. Cyanobacteria were known as a NiFe hydrogenase provider (Barz et al., 2010). They play two different NiFe types: fixing nitrogen strain that an uptake enzyme and bidirectional group strains (Tamagnini et al., 2007).

Analysis of the composition of all bacteria and hydrogenase genes in one frame showed that 3 phyla were out group of hydrogenase from 9 phyla of bacteria that were identified (Figure 3). While two phyla i.e. Proteobacteria and Bacteroidetes were detected both $\mathrm{FeFe}$ and NiFe hydrogenase. Cyanobacteria was observed specific for $\mathrm{NiFe}$, while hydrogenase related to Firmicutes, Planctomycetes and Candidate Division were unique for FeFe gene. These results slightly different from the study of $\mathrm{FeFe}$ and NiFe hydrogenase from marine bacteria (Barz et al., 2010). They found that both genes were found in Proteobacteria, whereas $\mathrm{NiFe}$ detected in Actinobacteria, Bacteroidetes, Planctomyces. The differences may be due to different sample being used, thus causing different species were observed. In addition, a comparative study of hydrogenases diversity from genomic Clostridia showed that Clostridia genus (Firmicutes) have both $\mathrm{FeFe}$ and $\mathrm{NiFe}$, although FeFe was more abundant than NiFe (Calusinska, Happe, Joris, \& Wilmotte, 2010).

\subsection{Phylogenetic diversity of bacteria and hydrogenase genes}

The phylogenetic tree of bacterial diversity was constructed from 53 OTUs (Figure 4). The tree shows that the mat bacteria community was clustered into 9 groups. OTUs member of Cyanobacteria and Proteobacteria were the dominant taxa with 15 OTUs each. This result was similar with the numbers of clones belong to them which were the abundant ones (Figure 2). Whereas, OTUs from Acidobacteria and Planktomycetes were the least number. Cyanobacteria 16S rRNA gene diversity showed that the microbial mat contained Pseudanabaena sp., Leptolyngbya sp., Halomicronema sp., Stanieria cyanosphaera, Neolyngbya maris-brasilis. These species were known as members of mat bacterial 


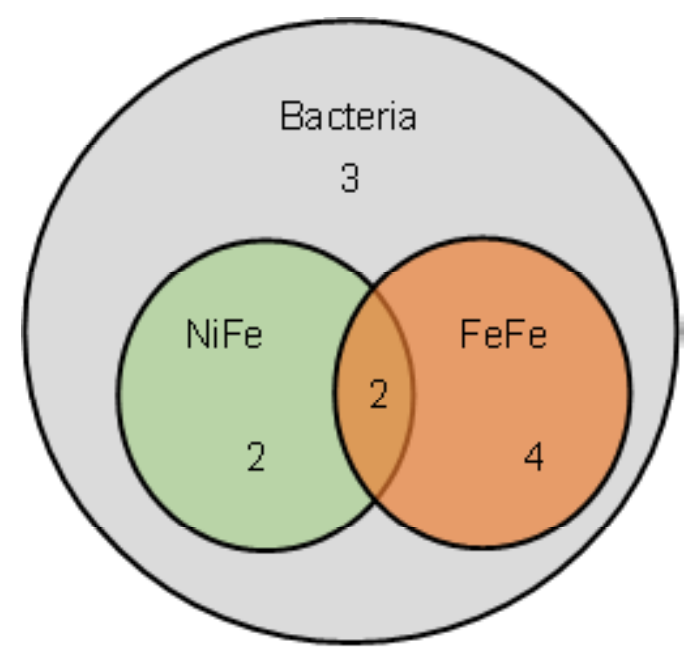

Figure 3. Venn diagram of bacterial and hydrogenase genes compositions of a microbial mat from hot spring at Wartawan, Lampung at the phylum level.

communities (Fourçans et al., 2006; Jungblut et al., 2016) except Stanieria cyanosphaera, Neolyngbya maris-brasilis which from marine benthics (Caires et al., 2018; Silva \& Pienaar, 2000). In addition, Pseudanabaena sp., Leptolyngbya sp. were found inhabited in cold temperature (Jungblut et al., 2016), whereas Halomicronema $s p$. in hypersaline mat (Fourçans et al., 2006). These results indicate that Cyanobacteria could survived not only in hot temperature but also in various environmental conditions. Furthermore, despite Pseudanabaena sp. and Leptolyngbya sp. have not reported yet as a hydrogenase producer, based on genomic studied showed that their genome containing hydrogenase gene (Puggioni, Tempel, \& Latifi, 2016).

Within Proteobacteria phylum, the largest class was Alphaproteobacteria ( $86.67 \%$ ) followed by Deltaproteobacteria (13.33\%). Other classes which were commonly founded in mat environments were Betaproteobacteria, Gammaproteobacteria, Epsilonproteobacteria, Zetaproteobacteria (Engel, Porter, Stern, Quinlan, \& Bennett, 2004; Selvarajan, Sibanda, \& Tekere, 2017). In addition, Zetaproteobacteria was unique to iron-oxidizing marine systems (Scott, Breier, Luther III, \& Emerson, 2015). Although, the mat from hot spring at Padang Cermin is also located at the beach, this class was not detected. The different result may be due to the chemical compositions of the hot spring and the method that used. Parvularcula lutaonensis, Thalassobius aestuarii and Desulfoglaeba sp. were some of the Proteobacteria members that were observed. P. lutaonensis, moderately thermotolerant species was isolated from a coastal hot spring (Arun et al., 2009). while mesophile $T$. aestuarii was obtained from marine sediment (Yi \& Chun, 2006). Desulfoglaeba $s p$. was recognized as a sulfate- reducing bacterium (SRB) (Davidova, Duncan, Choi, \& Suflita, 2006). This group of bacteria obtain energy from organic compounds and sulfate by oxidizing and reducing them respectively. The residue of sulfate will be used by other organisms for growth (Hao, Chen, Huang, \& Buglass, 1996). These results suggested that the microbial mat environment was inhabited by various type of Proteobacteria.

Firmicutes phylum was recognised as extremophile group members. They can survive at extreme temperature, salinity and $\mathrm{pH}$ (Canganella \& Wiegel, 2011). In this study, we only found one class of Firmicutes which was Bacilli. Further, this classis divided into Bacillus coahuilensis, $B$. thuringiensis and Exiguobacterium profundum, E. arabatum species. $B$. coahuilensis is a moderate halophilic that can tolerate $0.5-10 \% \mathrm{NaCl}$ (Cerritos et al., 2008), while $E$. profundum, a moderate thermophile which was isolated from a deep sea hydrothermal, can survive at 12 to $49^{\circ} \mathrm{C}$ (Crapart et al., 2007). In the Bacteroidetes phylum we found Lewinella cohaerens, Ekhidna lutea, Hymenobacter sp., Flavobacterium sp., Rhodothermaceae bacterium. Many Lewinella species were isolated from marine environments including marine sediment, sea water and sea snail (Khan, Fukunaga, Nakagawa, \& Harayama, 2007; Lee, 2007; Oh, Lee, \& Cho, 2009). Similarly, E. lutea was inhabited in sea water (Alain, Tindall, Catala, Intertaglia, \& Lebaron, 2010). These results indicate that a microbial mat from hot spring at Wartawan beach environment was influenced by marine environment and hydrothermal vent. The others phyla were not discussed because the number of OTUs were small.

The phylogenetic diversity of two type hydrogenase genes, $\mathrm{NiFe}(\mathrm{Hox})$ and FeFe (HydA) were analyzed in this study. NiFe was grouped into 8 categories. 


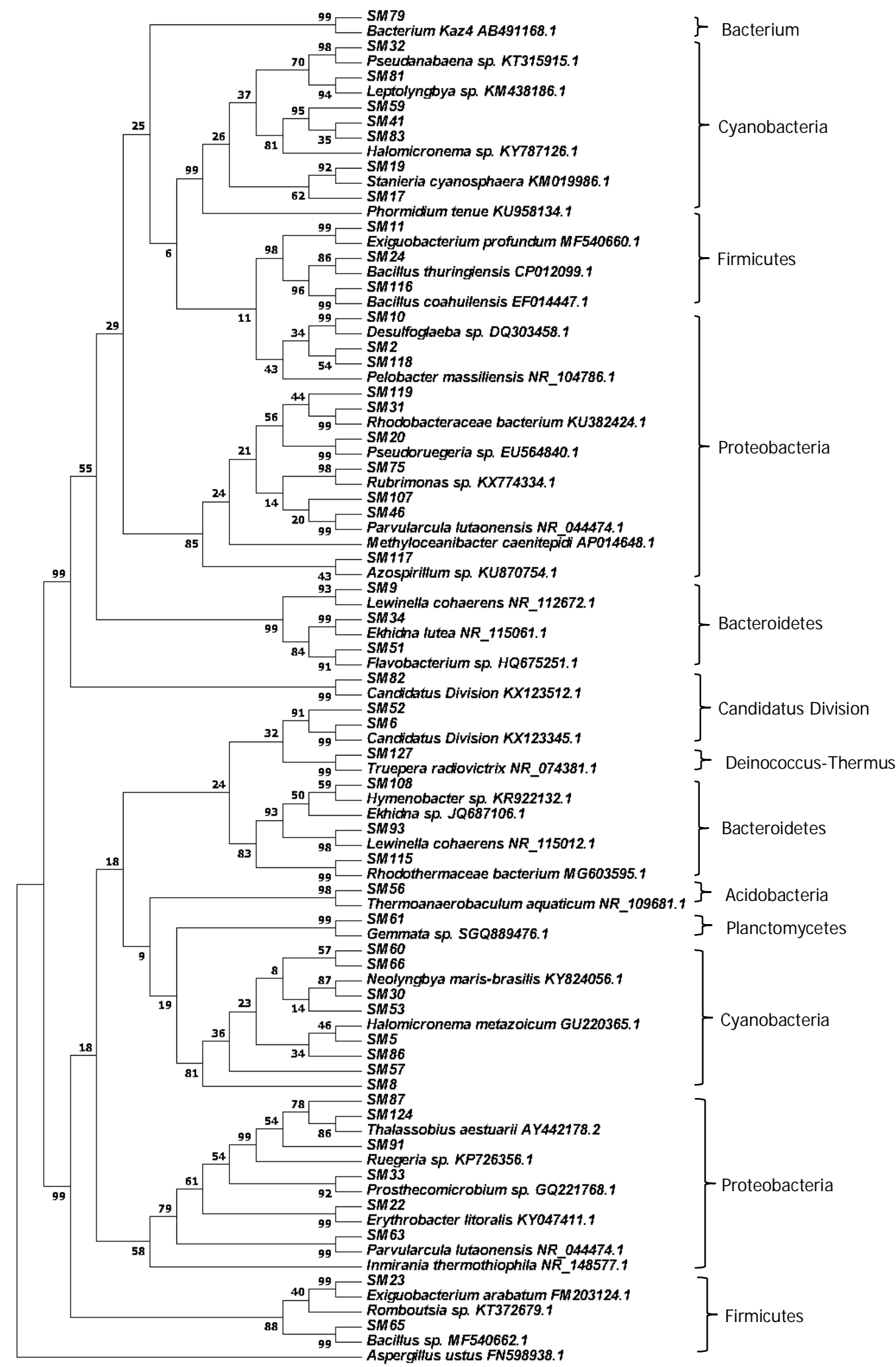

Figure 4. Bacterial 16S rRNA gene phylogenetic tree of a microbial mat from hot spring at Wartawan beach, Lampung using Maximum Parsimony analysis. The tree was generated from 53 OUTs with MEGA 7.0 software using 1000 replicates of bootstrap test. Number that was shown next to the branches showed the confidence levels to the nodes of the trees. 


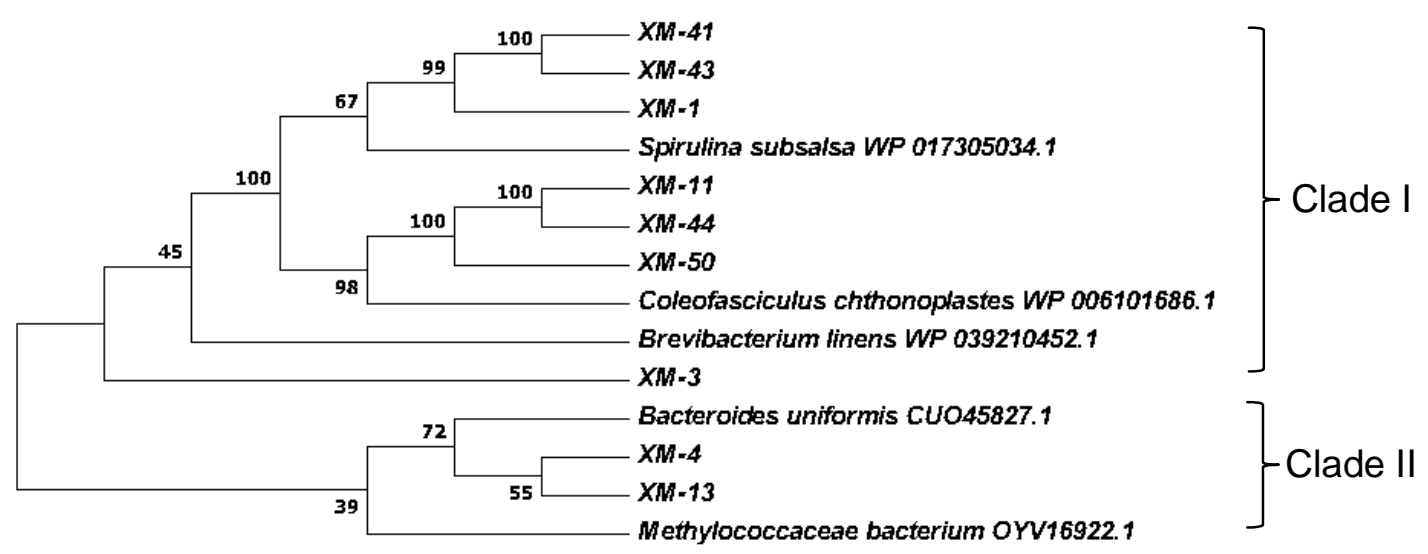

Figure 5. Partial amino acid sequence NiFe gene phylogenetic tree of a microbial mat from hot spring at Wartawan beach, Lampung using Maximum Parsimony analysis. The tree was generated from 9 OUTs with MEGA 7.0 software using 1000 replicates of bootstrap test. Number that was shown next to the branches showed the confidence levels to the nodes of the trees.

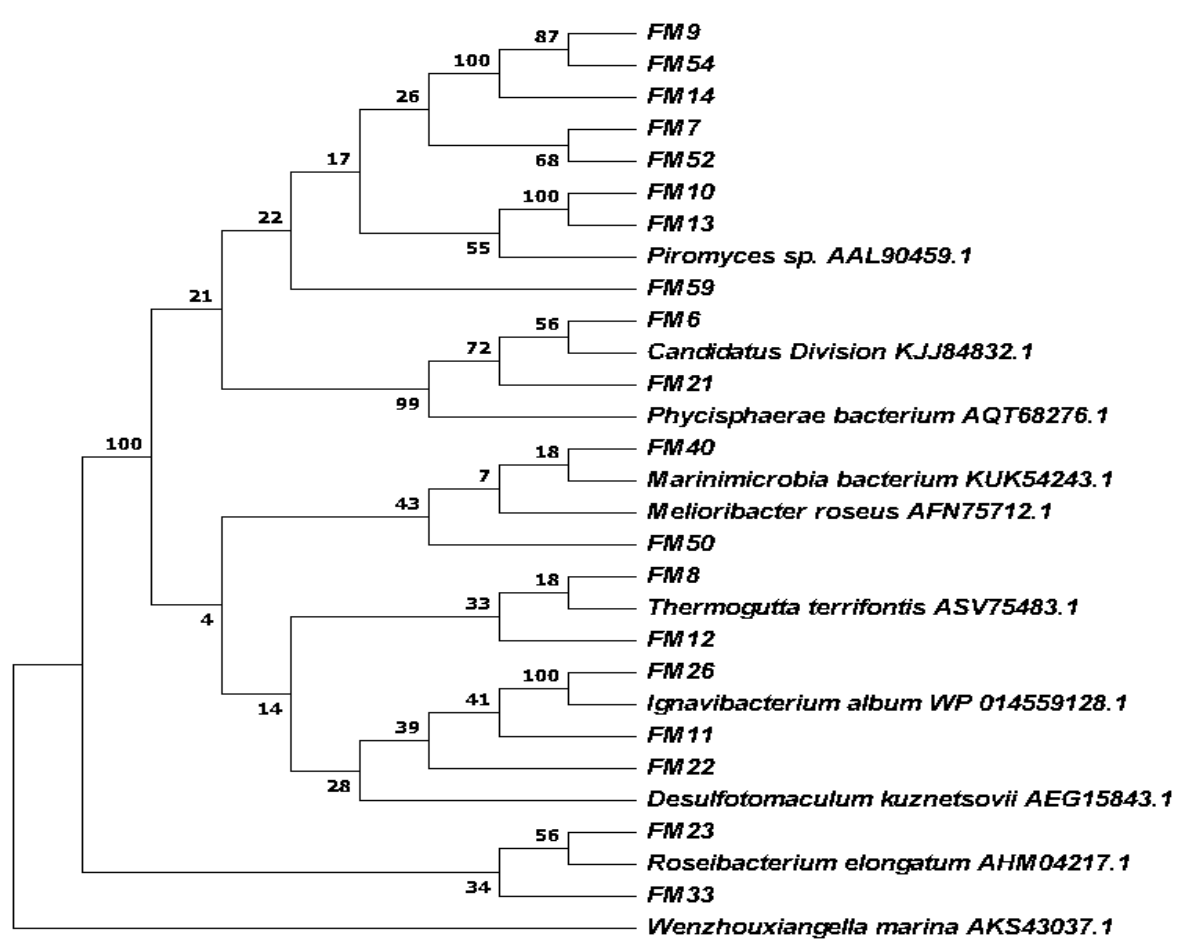

Figure 6. Partial amino acid sequence FeFe gene phylogenetic tree of a microbial mat from hot spring at Wartawan beach, Lampung using Maximum Parsimony analysis. The tree was generated from 19 OUTs with MEGA 7.0 software using 1000 replicates of bootstrap test. Number that was shown next to the branches showed the confidence levels to the nodes of the trees.

Especially Hox gene, grouped 3d, was bidirectional NAD $(P)$-linked hydrogenases that consumed or produced hydrogen. Whereas FeFe was periplasmic and cytoplasmic enzymes which have role as hydrogen oxidizing and evolving respectively. This enzyme was not divided into groups yet (Barz et al., 2010). Generally, the diversity of NiFe was categorized into two clades (Figure 5). NiFe Clade I was similar to
NiFe from Spirulina subsulsa, Coleofasciculus chthonoplastes and Brevibacterium linens. While Clade II was similar to Bacteroides uniformis and Methylococcaceae bacterium. These clades were not related with the phylum of each OUT. Although there are no report stating the cause of the difference between clades in hox gene, the difference may be because of the environmental sources of the gene. 
The study of distribution hydrogenases from surface of marine and fresh water showed that the hydrogenase of Spirulina subsulsa was obtained from ocean, while Methylococcaceae group was dominant in the lake (Barz et al., 2010).

The FeFe gene diversity of a microbial mat from hot spring at Wartawan beach is shown in Figure 6 . Although the FeFe hydrogenase was not grouped yet, the diversity of this gene formed several clades. Each clade, however, was not correlated to their phylum. For instance, Ignavibacterium album (Bacteroidates) formed clade with Desulfotomaculum kuznetsovii (Firmicutes). Based on the genomic and metagenomics study, Greening et al. proposed three groups of FeFe gene namely, a fermentative and bifurcating hydrogenases (group A), an ancestral group with unknown function (group B) and a putative sensory hydrogenases (group C). However, these classifications were only based on phylogenetic tree with poor bootstrap of the group $A$ and lack of functional information on the group $B$ and $C$ enzymes (Greening et al., 2016).

Comparision between the diversity of $16 \mathrm{~S}$ rRNA and hydrogenase genes in the species level showed that no species in the 16S rRNA were presented in the hydrogenase genes, although at the phylum level it had a cross-link. The difference might be because some of the 16S rRNA and hydrogenase amino acid sequence had low similarity to their closest matches.

\section{Conclusion}

The bacteria diversity of a microbial mat from hot spring at Wartawan beach, Lampung showed that the mat was dominated by Cyanobacteria, Proteobacteria, Bacteroidetes, and Firmicutes. These phyla indicate that the bacterial community of microbial mat consisted of phototrophic and heterotrophic groups that supported energy to other trophic levels. In addition, microbial mat from hot spring at Wartawan beach might be influenced by marine environment and hydrothermal vent that was indicated by detection of both associated bacteria. The detected hydrogenase genes, indicates that microbial mat of Wartawan beach is promising sources for hydrogenases isolation. Further study is needed to isolate the hydrogenases by both cultivation and metagenome methods and their application for hydrogen production as renewable energy.

\section{Acknowledgment}

This research was part of collaboration between Research and Development Center for Marine and Fisheries Product Processing and Biotechnology,
Indonesia and The First Institute of Oceanography, China. Financial support was obtained from budget of Ministry of Marine Affairs and Fisheries and Basic Scientific Fund for National Public Research Institutes of China; Key Lab of Marine Bioactive Substance and Modern Analytical Technique, SOA. The authors thank to Dewi Seswita Zilda, Agusman and Shou-Ying Xu for their help during laboratory analysis. Also, thanks to Hedi Indra Januar for the statistical analysis.

\section{References}

Alain, K., Tindall, B. J., Catala, P., Intertaglia, L., \& Lebaron, P. (2010). Ekhidna lutea gen. nov., sp. nov., a member of the phylum Bacteroidetes isolated from the South East Pacific Ocean. Int. J. Syst. Evol. Microbiol., 60(12), 2972-2978. doi:10.1099/ijs.0.018804-0

Amin, A., Ahmed, I., Salam, N., Kim, B.-Y., Singh, D., Zhi, X.-Y., . . Li, W.-J. (2017). Diversity and distribution of thermophilic bacteria in hot springs of Pakistan. Microbial Ecol., 74(1), 116-127. doi:10.1007/s00248017-0930-1

Arun, A., Chen, W.-M., Lai, W.-A., Chou, J.-H., Rekha, P., Shen, F.-T., . . . Young, C.-C. (2009). Parvularcula lutaonensis sp. nov., a moderately thermotolerant marine bacterium isolated from a coastal hot spring. Int. J. Syst. Evol. Microbiol., 59(5), 998-1001. doi:10.1099/ijs.0.004481-0

Baba, R., Asakawa, S., \& Watanabe, T. (2016). H2producing bacterial community during rice straw decomposition in paddy field soil: Estimation by an analysis of [FeFe]-hydrogenase gene transcripts. Microb. Environ., 31(3), 226-233. doi:10.1264/ jsme2.ME16036

Barz, M., Beimgraben, C., Staller, T., Germer, F., Opitz, F., Marquardt, C.,...Schmitz, R. (2010). Distribution analysis of hydrogenases in surface waters of marine and freshwater environments. PLoS One, 5(11), e13846. doi:10.1371/journal.pone.0013846

Boyd, E. S., Spear, J. R., \& Peters, J. W. (2009). [FeFe] hydrogenase genetic diversity provides insight into molecular adaptation in a saline microbial mat community. Appl. Environ. Microbiol., 75(13), 46204623. doi:10.1128/AEM.00582-09

Caires, T. A., de Mattos Lyra, G., Hentschke, G. S., de Gusmão Pedrini, A., Sant'Anna, C. L., \& de Castro Nunes, J. M. (2018). Neolyngbya gen. nov. (Cyanobacteria, Oscillatoriaceae): A new filamentous benthic marine taxon widely distributed along the Brazilian coast. Mol. Phylo. Evol., 120, 196-211. doi:10.1016/j.ympev.2017.12.009

Calusinska, M., Happe, T., Joris, B., \& Wilmotte, A. (2010). The surprising diversity of clostridial hydrogenases: a comparative genomic perspective. Microbiology, 156(6), 1575-1588. doi:10.1099/mic.0.032771-0

Canganella, F., \& Wiegel, J. (2011). Extremophiles: from abyssal to terrestrial ecosystems and possibly beyond. Naturwissenschaften, 98(4), 253-279. doi:10.1007/s00114-011-0775-2 
Cerritos, R., Vinuesa, P., Eguiarte, L. E., Herrera-Estrella, L., Alcaraz-Peraza, L. D., Arvizu-Gomez, J. L., . . . Souza, V. (2008). Bacillus coahuilensis sp. nov., a moderately halophilic species from a desiccation lagoon in the Cuatro Cienegas Valley in Coahuila, Mexico. Int. J. Syst. Evol. Microbiol., 58(4), 919-923. doi:10.1099/ijs.0.64959-0

Chen, J., Hanke, A., Tegetmeyer, H. E., Kattelmann, I., Sharma, R., Hamann, E., . . . Geelhoed, J. S. (2017). Impacts of chemical gradients on microbial community structure. The ISME J., 11(4), 920. doi:10.1038/ismej.2016.175

Crapart, S., Fardeau, M.-L., Cayol, J.-L., Thomas, P., Sery, C., Ollivier, B., \& Combet-Blanc, Y. (2007). Exiguobacterium profundum sp. nov., a moderately thermophilic, lactic acid-producing bacterium isolated from a deep-sea hydrothermal vent. Int. J. Syst. Evol. Microbiol., 57(2), 287-292. doi:10.1099/ ijs.0.64639-0

Das, D., \& Veziroglu, T. N. (2008). Advances in biological hydrogen production processes. Int. J. Hyd. Energy, 33(21), 6046-6057. j.ijhydene.2008.07.098

Davidova, I. A., Duncan, K. E., Choi, O. K., \& Suflita, J. M. (2006). Desulfoglaeba alkanexedens gen. nov., sp. nov., an n-alkane-degrading, sulfate-reducing bacterium. Int. J. Syst. Evol. Microbiol., 56(12), 2737 2742. doi:10.1099/ijs.0.64398-0

Eberly, J. O., \& Ely, R. L. (2008). Thermotolerant hydrogenases: biological diversity, properties, and biotechnological applications. Critical Rev. Microbiol., 34(3-4), 117-130. doi:10.1080/10408410802240893

Engel, A. S., Porter, M. L., Stern, L. A., Quinlan, S., \& Bennett, P. C. (2004). Bacterial diversity and ecosystem function of filamentous microbial mats from aphotic (cave) sulfidic springs dominated by chemolithoautotrophic "Epsilonproteobacteria". FEMS Microbiol. Ecol., 51(1), 31-53. doi:10.1016/ j.femsec.2004.07.004

Fang, H. H., Zhang, T., \& Li, C. (2006). Characterization of Fe-hydrogenase genes diversity and hydrogenproducing population in an acidophilic sludge. J. Biotechnol., 126(3), 357-364. doi:10.1016/ j.jbiotec.2006.04.023

Fourçans, A., Solé, A., Diestra, E., Ranchou Peyruse, A., Esteve, I., Caumette, P., \& Duran, R. (2006). Vertical migration of phototrophic bacterial populations in a hypersaline microbial mat from Salins de Giraud (Camargue, France). FEMS Microbiol. Ecol., 57(3), 367-377. doi:10.1111/j.1574-6941.2006.00124.x

Fullerton, H., Hager, K. W., McAllister, S. M., \& Moyer, C. L. (2017). Hidden diversity revealed by genomeresolved metagenomics of iron-oxidizing microbial mats from Lô'ihi Seamount, Hawai'i. The ISME J., 11(8), 1900. doi:10.1038/ismej.2017.40

Good, I. J. (1953). The population frequencies of species and the estimation of population parameters. Biometrika, 40(3-4), 237-264.

Greening, C., Biswas, A., Carere, C. R., Jackson, C. J., Taylor, M. C., Stott, M. B.,... Morales, S. E. (2016). Genomic and metagenomic surveys of hydrogenase distribution indicate $\mathrm{H} 2$ is a widely utilised energy source for microbial growth and survival. The ISME J., 10(3), 761. doi:10.1038/ismej.2015.153

Guerrero, R., Piqueras, M., \& Berlanga, M. (2002). Microbial mats and the search for minimal ecosystems. Int. Microbiol., 5(4), 177-188. doi:10.1007/s10123-002-0094-8

Hager, K. W., Fullerton, H., Butterfield, D. A., \& Moyer, C. L. (2017). Community Structure of Lithotrophically-Driven Hydrothermal Microbial Mats from the Mariana Arc and Back-Arc. Front. Microbiol., 8, 1578. doi:10.3389/ fmicb.2017.01578

Hammer, Ø., Harper, D.A.T. and Ryan, P.D. (2001). PastPaleontological Statistics. www.uv.es/-pardomv/pe/ 2001_1/past/pastprog/past.pdf,acesado em, 25 (07), 2009.

Hao, O. J., Chen, J. M., Huang, L., \& Buglass, R. L. (1996). Sulfate reducing bacteria. Critical Rev. Environ. Sci. Technol., 26(2), 155-187. doi:10.1080/ 10643389609388489

http://maps.google.co.id/. Retrieved from http://maps. google.co.id/

Jungblut, A. D., Hawes, I., Mackey, T. J., Krusor, M., Doran, P. T., Sumner, D. Y., ... Goroncy, A. K. (2016). Microbial mat communities along an oxygen gradient in a perennially ice-covered Antarctic lake. Appl. Environ. Microbiol., 82(2), 620-630. doi:10.1128/AEM.0269915

Karadag, D., Mäkinen, A. E., Efimova, E., \& Puhakka, J. A. (2009). Thermophilic biohydrogen production by an anaerobic heat treated-hot spring culture. Bioresource Technol., 100(23), 5790-5795. doi:10.1016/j.biortech.2009.06.035

Khan, S. T., Fukunaga, Y., Nakagawa, Y., \& Harayama, S. (2007). Emended descriptions of the genus Lewinella and of Lewinella cohaerens, Lewinella nigricans and Lewinella persica, and description of Lewinella lutea sp. nov. and Lewinella marina sp. nov. Int. J. Sys. Evol. Microbiol., 57(12), 2946-2951. doi:10.1099/ijs.0.65308-0

Kim, D.-H., \& Kim, M.-S. (2011). Hydrogenases for biological hydrogen production. Bioresource Technol., 102(18), 8423-8431. doi:10.1016/ j.biortech.2011.02.113

Kothari, A., Potrafka, R., \& Garcia-Pichel, F. (2012). Diversity in hydrogen evolution from bidirectional hydrogenases in cyanobacteria from terrestrial, freshwater and marine intertidal environments. $J$. Biotechnol., 162(1), 105-114. doi:10.1016/ j.jbiotec.2012.04.017

Kruse, F. (1999). Mapping hot spring deposits with AVIRIS at Steamboat Springs, Nevada. Paper presented at the Proceedings of the 8th JPL Airborne Earth Science Workshop: Jet Propulsion Laboratory Publication 99.

Kumar, S., Stecher, G., \& Tamura, K. (2016). MEGA7: molecular evolutionary genetics analysis version 7.0 for bigger datasets. Mol. Biol. Evol., 33(7), 1870-1874. doi:10.1093/molbev/msw054

Lau, M. C., Aitchison, J. C., \& Pointing, S. B. (2009). Bacterial community composition in thermophilic microbial mats from five hot springs in central Tibet. Extremophiles, 13(1), 139-149. doi:10.1007/s00792008-0205-3 
Lee, S. D. (2007). Lewinella agarilytica sp. nov., a novel marine bacterium of the phylum Bacteroidetes, isolated from beach sediment. Int. J. Sys. Evol. Microbiol., 57(12), 2814-2818. doi:10.1099/ ijs.0.65254-0

Lemos, L. N., Fulthorpe, R. R., Triplett, E. W., \& Roesch, L. F. (2011). Rethinking microbial diversity analysis in the high throughput sequencing era. J. of Microbiol. Methods, 86(1), 42-51. doi:10.1016/ j.mimet.2011.03.014

Li, C., \& Fang, H. H. (2007). Fermentative hydrogen production from wastewater and solid wastes by mixed cultures. Critical Rev. Environ. Sci.Technol., 37(1), 1-39. doi:10.1080/10643380600729071

Minnan, L., Jinli, H., Xiaobin, W., Huijuan, X., Jinzao, C., Chuannan, L., . . . Liangshu, X. (2005). Isolation and characterization of a high $\mathrm{H} 2$-producing strain Klebsiella oxytoca HP1 from a hot spring. Research Microbiol., 156(1), 76-81. doi:10.1016/ j.resmic.2004.08.004

Morris, E. K., Caruso, T., Buscot, F., Fischer, M., Hancock, C., Maier, T. S., ... Prati, D. (2014). Choosing and using diversity indices: insights for ecological applications from the German Biodiversity Exploratories. Ecol. Evol., 4(18), 3514-3524. doi:10.1002/ece3.1155

Moyer, C. L., Dobbs, F. C., \& Karl, D. M. (1995). Phylogenetic diversity of the bacterial community from a microbial mat at an active, hydrothermal vent system, Loihi Seamount, Hawaii. Appl. Environ. Microbiol., 61(4), 1555-1562.

Nandi, R., \& Sengupta, S. (1998). Microbial production of hydrogen: an overview. Critical Rev. Microbiol., 24(1), 61-84.

Oh, H.-M., Lee, K., \& Cho, J.-C. (2009). Lewinella antarctica sp. nov., a marine bacterium isolated from Antarctic seawater. Int. J. Sys. Evol. Microbiol., 59(1), 65-68. doi:10.1099/ijs.0.000794-0

Preisner, E. C., Fichot, E. B., \& Norman, R. S. (2016). Microbial Mat Compositional and Functional Sensitivity to Environmental Disturbance. Front Microbiol., 7, 1632. doi:10.3389/fmicb.2016.01632

Puggioni, V., Tempel, S., \& Latifi, A. (2016). Distribution of Hydrogenases in Cyanobacteria: A Phylum-Wide Genomic Survey. Front. Genet., 7, 223. doi:10.3389/ fgene.2016.00223

Quéméneur, M., Hamelin, J., Benomar, S., GuidiciOrticoni, M.-T., Latrille, E., Steyer, J.-P., \& Trably, E. (2011). Changes in hydrogenase genetic diversity and proteomic patterns in mixed-culture dark fermentation of mono-, di-and tri-saccharides. Int. J. Hyd. Energy, 36(18), 11654-11665. doi:10.1016/ j.ijhydene.2011.06.010

Schieber, J., Bose, P. K., Eriksson, P., Banerjee, S., Sarkar, S., Altermann, W., \& Catuneanu, O. (2007). Atlas of microbial mat features preserved within the siliciclastic rock record (Vol. 2): Elsevier.

Schmidt, O., Drake, H. L., \& Horn, M. A. (2010). Hitherto unknown [Fe-Fe]-hydrogenase gene diversity in anaerobes and anoxic enrichments from a moderately acidic fen. Appl. Environ. Microbiol., 76(6), 2027-2031. doi:10.1128/AEM.02895-09
Scott, J. J., Breier, J. A., Luther III, G. W., \& Emerson, D. (2015). Microbial iron mats at the Mid-Atlantic Ridge and evidence that Zetaproteobacteria may be restricted to iron-oxidizing marine systems. PLoS One, 10(3), e0119284. doi:10.1371/journal.pone.0119284

Selvarajan, R., Sibanda, T., \& Tekere, M. (2017). Thermophilic bacterial communities inhabiting the microbial mats of "indifferent" and chalybeate (iron rich) thermal springs: Diversity and biotechnological analysis. MicrobiologyOpen, 560, 1-12. doi:10.1002/ $\mathrm{mbo3.560}$

Show, K., Lee, D., Tay, J., Lin, C., \& Chang, J. (2012). Biohydrogen production: current perspectives and the way forward. Int. J. Hyd. Energy, 37(20), 15616-15631. doi:10.1016/j.ijhydene.2012.04.109

Silva, S. M., \& Pienaar, R. N. (2000). Benthic Marine Cyanophyceae from Kwa-Zulu Natal,-South Africa. Berlin: J Cramer.

Tamagnini, P., Leitão, E., Oliveira, P., Ferreira, D., Pinto, F., Harris, D. J., . . . Lindblad, P. (2007). Cyanobacterial hydrogenases: diversity, regulation and applications. FEMS Microbiol. Rev., 31(6), 692-720. doi:0.1111/ j.1574-6976.2007.00085.x

Vignais, P. M., Billoud, B., \& Meyer, J. (2001). Classification and phylogeny of hydrogenases. FEMS Microbiol. Rev., 25(4), 455-501. doi:10.1111/j.15746976.2001.tb00587.x

Ward, D. M., Ferris, M. J., Nold, S. C., \& Bateson, M. M. (1998). A natural view of microbial biodiversity within hot spring cyanobacterial mat communities. Microbiol. Mol. Biol. Rev., 62(4), 1353-1370.

Xing, D., Ren, N., \& Rittmann, B. E. (2008). Genetic diversity of hydrogen-producing bacteria in an acidophilic ethanol-H2-coproducing system, analyzed using the [Fe]-hydrogenase gene. Appl. Environ. Microbiol., 74(4), 1232-1239. doi:10.1128/ AEM.01946-07

Xu, S.-Y., He, P.-Q., Dewi, S.-Z., Zhang, X.-L., Ekowati, C., Liu, T.-J., \& Huang, X.-H. (2013). Hydrogen-producing microflora and $\mathrm{Fe}-\mathrm{Fe}$ hydrogenase diversities in seaweed bed associated with marine hot springs of Kalianda, Indonesia. Curr. Microbiol., 66(5), 499-506. doi:10.1007/s00284-013-0302-0

Yi, H., \& Chun, J. (2006). Thalassobius aestuarii sp. nov., isolated from tidal flat sediment. The J. Microbiol., 44(2), 171-176.

Zilda, D. S., Harmayani, E., Widada, J., Asmara, W., Irianto, H. E., Patantis, G., \& Fawzya, Y. N. (2012). Screening of thermostable protease producing microorganisms isolated from Indonesian hotspring. Squalen Bull. Mar. Fish. Postharvest Biotech., 7(3), 105-114. doi:10.15578/squalen.v7i3.5

Zilda, D. S., Kusumarini, A., \& Chasanah, E. (2008). Penapisan dan Karakterisasi Protease dari Bakteri Termo-Asidofilik P5-A dari Sumber Air Panas Tambarana. Jurnal Pascapanen dan Bioteknologi Kelautan dan Perikanan, 3(2), 113-121. doi:10.15578/ jpbkp.v3i2.17

Zilda, D. S., Patantis, G., \& Chasanah, E. (2009). The use of restriction fragment length polymorphism (RFLP) technique for assessing genetic diversity of thermophilic bacteria. J. Mar. Fish. Postharvest Biotec., 4, 37-43. 